\title{
NOTES
}

\section{EXPERIMENTAL BACILLARY DYSENTERY IN RABBITS}

In reproducing shigellosis similar to that of human beings, monkeys have so far been employed as the most suitable experimental animal (Honjo et al., 1964; Ogawa et al., 1964 and 1966 ; Formal, LaBrec and Schneider, 1965 ; Voino-Yasenetsky, 1965). Recently, some experimental models for Shigella infection, using laboratory animals other than monkeys, have also been developed. However, they could not always be relied upon for precise reproduction of the characteristics of shigellosis in naturally susceptible hosts, particulary in reference to clinical manifestation; besides, some of the models were hardly reproducible (unpublished data).

Though rabbits are not naturally susceptible to Shigella, a short-term infection with Shigella was reported independently by two authors using the ligated segments of the small intestine of rabbits (Kasuga et al., 1963; Arm et al., 1965). By washing off the intestinal contents, Kasuga et al. (1963) could obtain good result. These facts suggest that the rabbit intestine does not completely lack in the susceptibility to Shigella, and that a certain conditioning for inoculation may make it possible to reproduce shigellosis accompanied by clinical signs in rabbits.

The present report deals with a successful attempt for producing in rabbits experimental bacillary dysentery with a longer observation during the course of the disease which was similar to that in monkeys previously reported by the authors (Honjo et al., 1964 ; Ogawa et al., 1964 and 1966).

Commercial rabbits of both sexes, weighing about $3 \mathrm{~kg}$ were employed. The animals were starved for $48 \mathrm{hr}$ before operation and anesthetized by intravenous injection with 50 to $100 \mathrm{mg}$ of sodium isomytal (Nippon Shinyaku Co., Ltd.). The abdomen was opened by midline incision, and the colon was segmented by pinching with two hair clips, one placed at a proximal part and the other at a distance of $20 \mathrm{~cm}$ from there. The lumen of the segment was washed with about $500 \mathrm{ml}$ of saline until washings became clear. Clip at the distal part was then removed, and $2 \mathrm{ml}$ of a bacterial suspension, containing $10^{8}$ or $10^{9} / \mathrm{ml}$ organisms, was inoculated into the proximal part of the segment. The abdomen was closed with sutures. About $5 \mathrm{hr}$ after that, the clip at the proximal part was removed and animals were fed. The bacterial strains used here were Shigella flexneri 2a, strain 5503 (virulent) and its colonial variant strain 5503 I (smooth form, avirulent). The origin and the virulence characteristics of those strains have been previously reported (Ogawa et al., 1967). Animals were arbitrarily sacrificed according to the course of infection. Microscopical observations on the characteristics of the intestinal lesion and distribution of bacilli in the tissue were carried out by ordinary hematoxylin-eosin stain and direct fluorescent antibody techniques 
Table 1. Summary of clinical and pathological findings

\begin{tabular}{|c|c|c|c|c|c|c|c|c|}
\hline \multirow{2}{*}{ Inocula } & \multirow{2}{*}{$\begin{array}{l}\text { No. of } \\
\text { animal } \\
\text { used }\end{array}$} & \multicolumn{2}{|c|}{ Animals } & \multirow{2}{*}{$\begin{array}{c}\text { Clinical sign } \\
\text { Characteristics } \\
\text { of stool }\end{array}$} & \multirow{2}{*}{ No. } & \multirow{2}{*}{$\begin{array}{l}\text { No. of } \\
\text { Shigella } \\
\text { in rectal } \\
\text { contents } \\
\text { (per gr) }\end{array}$} & \multicolumn{2}{|c|}{ Histo-pathological } \\
\hline & & Fate & No. & & & & $\begin{array}{l}\text { Bacterial } \\
\text { invasion** }\end{array}$ & Inflammation \\
\hline \multirow{9}{*}{$\begin{array}{l}\text { Strain } 5503 \\
3-5 \times 10^{8}\end{array}$} & \multirow{6}{*}{18} & D-2 & 4 & mucus with blood & 4 & $>10^{8}$ & m & severe \\
\hline & & S-2 & 5 & muco-purulent & 1 & & m & severe \\
\hline & & & & bloody mucous & 2 & $>10^{8}$ & H & severe \\
\hline & & & & mucous & 2 & & H & moderate \\
\hline & & S-5 & 4 & mucous normal & 4 & $<10^{4}$ & +-- & $\begin{array}{l}\text { slight } \sim \text { no } \\
\text { noticeable } \\
\text { change }\end{array}$ \\
\hline & & S-7 & 5 & $\begin{array}{l}\text { (bloody-) mucous } \\
\text { normal }\end{array}$ & 5 & - & - & $\begin{array}{l}\text { no noticeable } \\
\text { change }\end{array}$ \\
\hline & \multirow[t]{3}{*}{$6^{*}$} & S-2 & 3 & $\begin{array}{l}\text { normal or } \\
\text { slightly loose }\end{array}$ & 3 & $10^{6}$ & \pm-- & $\begin{array}{l}\text { slight } \sim \text { no } \\
\text { noticeable } \\
\text { change }\end{array}$ \\
\hline & & S-7 & 3 & normal & 3 & - & - & $\begin{array}{l}\text { no noticeable } \\
\text { change }\end{array}$ \\
\hline & & S-2 & 2 & normal & 2 & $10^{7}$ & - & $\begin{array}{l}\text { no noticeable } \\
\text { change }\end{array}$ \\
\hline $\begin{array}{l}\text { Strain 5503-I } \\
\quad 1 \times 10^{9}\end{array}$ & 6 & S-7 & 4 & normal & 4 & - & - & $\begin{array}{l}\text { no noticeable } \\
\text { change }\end{array}$ \\
\hline
\end{tabular}

D-n: Died on $\mathrm{n}$ days after inoculation.

$\mathrm{S}-\mathrm{n}$ : Sacrificed on $\mathrm{n}$ days after inoculation.

*: Nontreated (neither washing nor pinching).

**: Fluorescing bacilli distributed massively in the epithelial lining and lamina propria. $\cdots \cdots+++$

The bacilli were diffusely found in the luminal epithelial lining but a few in the lamina propria. $\cdots \cdots++$

The bacilli were found in epithelial cells on the tip of villi.

A few epithelial cells in microfoci contained a limited number of bacilli. $\cdots \cdots \pm$

(Ogawa et al., 1964).

Clinical, bacteriological and histopathological findings of the intestine at various stages of infection are summarized in Table 1. Four rabbits which died immediately after inoculation showed bloody mucous diarrhea and their colons were widely, but not entirely, affected. The surface of the mucosa was partially covered with fibrinous or purulent exudates, mucosal folds were thickened due to edema, hemorrhagic and errosive in the affected areas. Histological examination revealed catarrhalic colitis accompanied by microulcer- and cryptabscess-formation. Fluorescing bacilli were found massively in those foci. Three animals which developed mucopurulent or bloody mucous diarrhea were sacrificed on the 2nd day. Severe lesions similar to those of dead animals occurred in the proximal part (Fig. 1), being localized with milder catarrhalic lesions in the distal part of the colon. Fluorescing bacilli were distributed mainly in the luminal epithelia. Two of the remaining animals which continued to excrete mucous (gelatinous) stool until the sacrifice time showed thickening of mucosal folds due to inflammatory edema and degeneration, and desquamation of the luminal epithelial lin- 
ing. A bairly large number of fluorescing bacilli were detected in those epithelial cells but a few in the lamina propria. Four animals sacrificed on the 5th day and 5 animals sacrificed on the 7 th day all manifested mucous or bloody mucous diarrhea during the period between the 1st and the 3rd or 4th day after inoculation, but stool became normal after that and remained so until the autopsy time. In those cases, noticeable gross lesions were absent, while, histologically, microfoci containing a few epithelial cells parasitized by bacilli were detected in a few cases. Animals which had colonic inoculation without washing of the lumen and obstruction of the proximal part, were autopsied, 3 at a time, on the 2nd and 7th days. Among them 2 animals excreted slightly loose stool, and were found to have mild catarrhalic foci in the proximal part at the earlier stage. When avirulent strain 5503 I was inoculated, no animal showed either clinical sign or pathological changes at any stage observed.

The number of $S$. flexneri 2 a in rectum stool was estimated at more than $10^{8}$ per gram in animals sacrificed or those which died at the peak of the disease after a virulent strain was inoculated. The bacilli decreased to less than $10^{4}$ per gram in the recovering stage and were not isolated from normal stool on the 7th day. In nontreated animals the number of bacilli was definitely small $\left(10^{6}\right.$ per gr) on the 2nd day and not detected on the 7th day. When the avirulent strain was inoculated, the bacilli were eliminated within the 7 th day, though they were estimated at $10^{7}$ per gram on the 2 nd day.

\section{DISCUSSION}

Though the ligated intestinal segments of rabbits could be infected with Shigella (Kasuga et al., 1963; Arm et al., 1965). Bacillary dysentery was not represented by the condition thus induced. The observations using this system are limited to the initial stage of infection as early as $24 \mathrm{hr}$. Therefore, an attempt was made to produce in rabbits bacillary dysentery which was similar to that of naturally susceptible hosts. Success in the experiment seemed to depend upon the conditioning, by which colonic contents were avoided while injected Shigella bacilli were allowed to penetrate the epithelial lining. This conditioning was maintained for $5 \mathrm{hr}$, since the bacterial penetration into the epithelia occurred 2 $\mathrm{hr}$ after the inoculation of the virulent strain into ligated intestinal segments of rabbits or keratoconjunctival sac of guinea pigs (Ogawa et al., 1967; Ogawa, to be published) and it seemed reasonably certain that in the present experiment 5 hr would be sufficient for penetration of such an amount of bacilli as was necessary for establishment of dysentery.

Factors responsible for rabbits' resistance to Shigella infection seemed to exist in the intestinal contents rather than in the intestinal wall. It is not clear whether they are related with microbes in the contents or with the physiological factors including secretions; this problems should further be studied.

Shigella infection pattern in rabbits described in the present report closely resembled that in monkeys (Honjo et al., 1964 ; Ogawa et al., 1964 and 1966), though the course of disease was short in rabbits which survived the initial attack. This shortness in the course of the disease in rabbits might be ascribed to resistant factors which their intestinal contents possess against Shigella. 


\section{ACKNOWLEDGEMENT}

The authors are indebted to Dr. Y. Egashira, Chief, Department of Pathology, National Institute of Health, for his valuable criticisms in preparation of this report.

\section{REFERENCES}

Arm, H. G., Floyd, T. M., FArber, J. E. ANd Hayes, J. R. (1965): Use of ligated segments of rabbit small intestine in experimental shigellosis. J. Bacteriol., 89, 803-809.

Formal, S. B., LABREC, E. H. AND Schneider, H. (1965): Pathogenesis of bacillary dysentery in laboratory animals. Fed. Proc., 24, 29-34.

Honjo, S., Takasaka, M., Fujiwara, T., Nakagawa, M., Ando, K., Ogawa, H., TakaHASHI, R. AND IMAIZUMI, K. (1964): Shigellosis in cynomolgus monkeys (Macaca irus). II. Experimental infection with Shigella flexneri 2a with special references to clinical and bacteriological findings. Japan. J. Med. Sci. Biol., 17, 307-319.

Kasuga, T., Ghoda, A., Kazuno, Y., Ushiba, D., Sasaki, S., Ujile, A., Kishimoto, Y., Watanabe, T., Kobari, T. And Sekiguchi, T. (1963): Studies on the mechanisms of infection and immunity in experimental shigellosis. Japan. J. Inf. Dis., 37, 249-261. (in Japanese)

Ogawa, H., Takahashi, R., Honjo, S., Takasaka, M., Fujiwara, T., Ando, K., NaKaGaWA, M., Muto, T. ANd Imaizumi, K. (1964): Shigellosis in cynomolgus monkeys (Macaca irus). III. Histopathological studies on natural and experimental shigellosis. Japan. J. Med. Sci. Biol., 17, 321-332.

Ogawa, H., Honjo, S., Takasaka, M., Fujiwara, T. And Imaizumi, K. (1964): Shigellosis in cynomolgus monkeys (Macaca irus). IV. Bacteriological and histopathological observations on the earlier stage of experimental injection with Shigella flexneri 2a. Japan. J. Med. Sci. Biol., 19, 23-32.

Ogawa, H., Nakamura, A., Nakaya, R., Mise, K., Honjo, S., TAKasaka, M., Fujiwara, T. AND IMAIZumi, K. (1967): Virulence and epithelial cell invasiveness of dysentery bacilli. Japan. J. Med. Sci. Biol., 20, 315-328.

OGAWA, H.: Experimental approach in studies on pathogenesis of bacillary dysentery. Asakura-Shoten, Tokyo, Japan. (in Japanese, to be published)

VoINO-YASENETSKY, M. V. (1965): The nature of intestinal affection in dysentery. Arch. Path. (Moscow), 28, 3-15. (in Russian)

Department of Pathology*

Department of Bacteriology I

National Institute of Health, Shinagawa-ku Tokyo 141, Japan

Received: September 26, 1969
HIDEMASA OGAWA*

AKIKO NAKAMURA

\footnotetext{
* Present adress: General Research Laboratory DAIICHI SEIYAKU CO., LTD. 2810, Minami-Funabori-cho Edogawa-ku, Tokyo, Japan.

小河秀正 (国立予防衛生研究所病理部; 現第一製薬株式会社綜合研究所)

中村明子 (国立予防衛生研究所細菌第一部)
} 


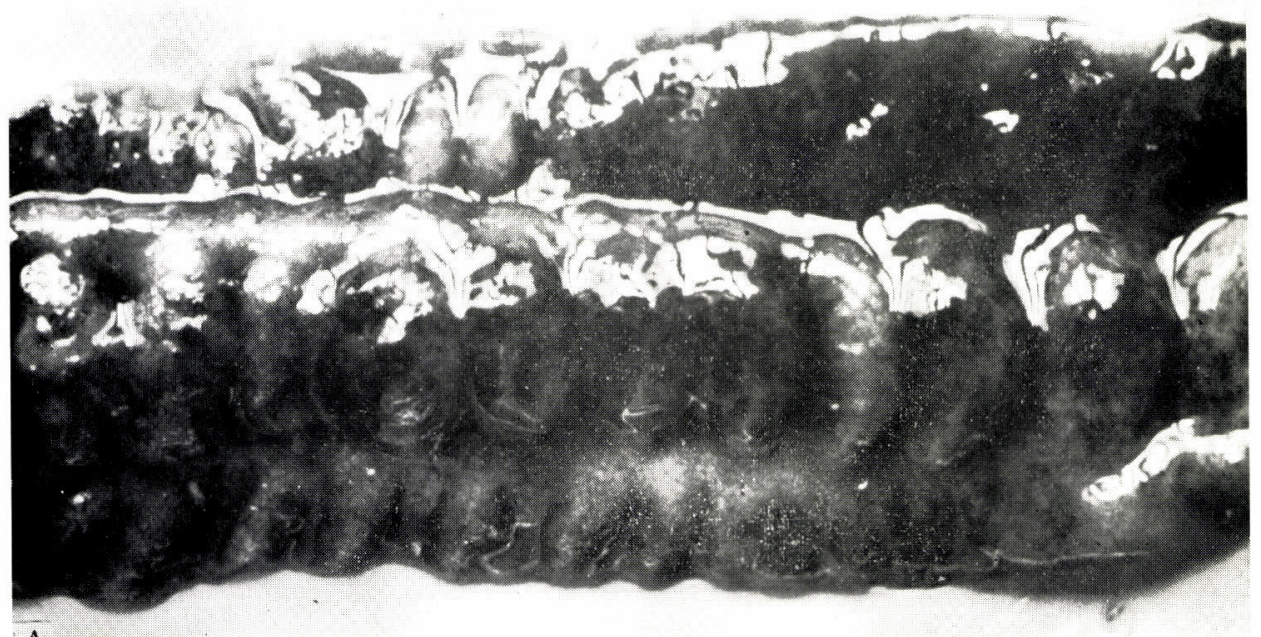

A
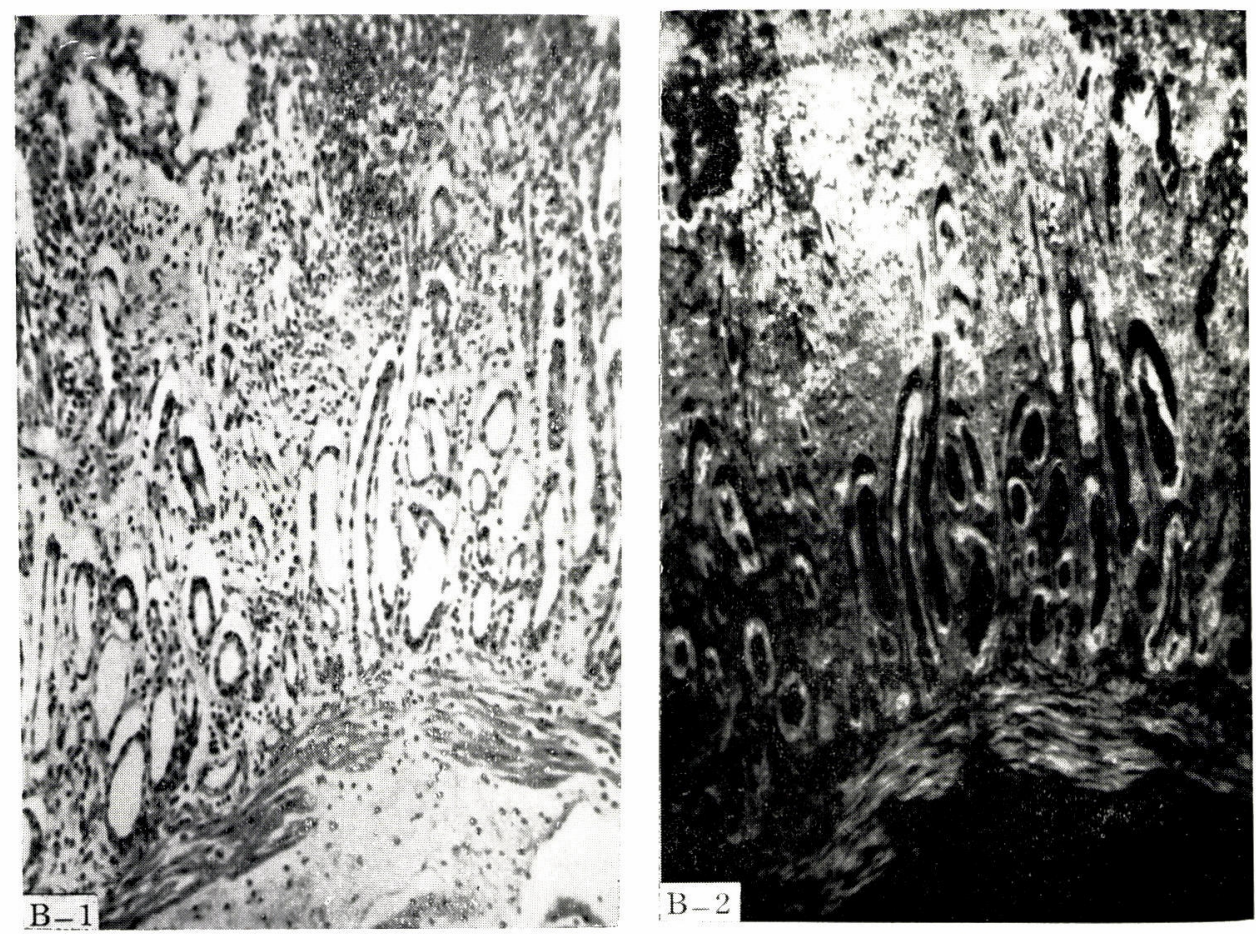

Fig. 1. Colonic lesions in a rabbit sacrificed on the 2 nd day after inoculation with the virulent strain. Mucous membrane was hemorrhagic errosive, and thickened due to edema (A). Exudative inflammation accompanied by microulcer and cryptabscess (B-1). Fluorescing bacilli were found massively in the epithelium and lamina propria (B-2). Original magnification: $\times 100$. 